(c) American Dairy Science Association, 2004.

\title{
Conjugated Linoleic Acid Increases in Milk When Cows Fed Fish Meal and Extruded Soybeans for an Extended Period of Time*
}

\author{
A. A. AbuGhazaleh,t, D. J. Schingoethe, A. R. Hippen, and K. F. Kalscheur \\ Dairy Science Department, \\ South Dakota State University, \\ Brookings 57007-0647
}

\section{ABSTRACT}

The objective of this study was to determine the effect of feeding a conjugated linoleic acid (CLA) stimulating diet for an extended period of time on milk cis-9, trans11 CLA and vaccenic acid (VA) concentrations. Twenty cows (16 Holstein and 4 Brown Swiss) were divided into 2 groups ( $\mathrm{n}=10$ per treatment) for a 10 -wk study. Cows in group 1 were fed a traditional corn-soybean-basal diet (control), while those in group 2 were fed a blend of $0.5 \%$ fish oil from fish meal and $2 \%$ soybean oil from extruded soybeans (FMESB) to achieve higher milk fat cis-9, trans-11 CLA and VA. Diets were formulated to contain $18 \% \mathrm{CP}$ and were composed (dry matter basis) of $50 \%$ concentrate mix, $25 \%$ corn silage, and $25 \%$ alfalfa hay. Dry matter intake was not affected by diet. Milk production increased in cows fed the FMESB diet. Milk fat and milk protein percentages decreased with the FMESB diet; however, milk fat and protein yields were not affected by treatments. Milk fat cis-9, trans11 CLA and VA concentration (g/100 of fatty acids) and yield $(\mathrm{g} / \mathrm{d})$ were 2.5 -fold greater for cows fed the FMESB diet over the $10 \mathrm{wk}$ of fat supplementation. For cows fed the FMESB diet, contents of milk fat cis-9, trans11 CLA and VA gradually increased from the first week of fat supplementation, reached the highest concentrations in wk 3, then gradually decreased during wk 4 and 5 and then remained relatively constant until wk 10. The concentration of cis-9, trans-11 CLA and VA from the control diet was relatively constant over the $10 \mathrm{wk}$ of fat supplementation. Concentrations of cis-9, trans-11 CLA and VA in milk fat can be increased within a week by feeding a blend of fish meal and ex-

Received May 15, 2003.

Accepted November 8, 2003.

Corresponding author: D. J. Schingoethe; e-mail: david schingoethe@sdstate.edu.

*Published with the approval of director of the South Dakota Agricultural Experiment Station as Publication Number \# 3364 of the Journal Series.

$†$ Present address: Department of Animal and Veterinary Science, Clemson University, Clemson, SC 29634. truded soybeans, and that increase remains relatively constant after wk 5 of fat supplementation.

(Key words: conjugated linoleic acid, vaccenic acid, milk fatty acids)

Abbreviation key: CLA = conjugated linoleic acid, DHA = docosahexaenoic acid, EPA = eicosapentaenoic acid, FMESB = fish meal and extruded soybeans, VA = vaccenic acid.

\section{INTRODUCTION}

Recent research has focused on increasing the amount of conjugated linoleic acid (cis-9, trans-11 CLA) and vaccenic acid (trans-11 C18:1; VA) in milk fat because of reported health benefits (Ip et al., 1999). The major CLA, cis-9, trans-11 CLA, is synthesized either in the rumen as an intermediate in the biohydrogenation of linoleic acid (C18:2 cis-9, cis-12) or in the tissues by delta-9 desaturase from VA, another intermediate in ruminal biohydrogenation (Griinari and Bauman, 1999). Piperova et al. (2002) showed that approximately 93\% of cis-9, trans-11 CLA appearing in milk fat is synthesized in the mammary gland from VA via delta9 desaturase. Additionally, human tissues also have the delta-9 desaturase to convert VA into cis-9, trans11 CLA (Salminen et al., 1998). Thus, an increase in VA consumption leads to the positive health responses associated with cis-9, trans-11 CLA consumption.

Dhiman et al. (2000) and Chouinard et al. (2001) reported that feeding lipid sources rich in mono- and polyunsaturated fatty acids, either as seeds, free oil, or calcium salts, increased the cis-9, trans-11 CLA and VA content of milk when oil is accessible to the rumen microorganisms for biohydrogenation. Our previous research (AbuGhazaleh et al., 2002; Whitlock et al., 2002) demonstrated that feeding a blend of fish oil and an unsaturated fat source was more effective in increasing milk fat content of cis-9, trans-11 CLA and VA than feeding them separately. Another recent study (AbuGhazaleh et al., 2003a) concluded that feeding a blend of fish oil and a linoleic acid source was the most effective in increasing milk fat content of cis-9, trans-11 CLA and VA. When fish oil and sunflower seeds (linoleic 
acid source) were fed, milk concentrations of cis-9, trans-11 CLA and VA averaged 1.7 and $3.74 \mathrm{~g} / 100 \mathrm{~g}$ of fatty acids, respectively (AbuGhazaleh et al., 2003a). Milk fat from cows fed a control diet (no added fat) contains approximately 0.4 and $0.75 \mathrm{~g} / 100 \mathrm{~g}$ fatty acids of cis-9, trans-11 CLA and VA (see AbuGhazaleh et al., 2002); therefore, feeding a blend of fish oil and unsaturated fat source such as extruded soybeans or sunflower seeds increased milk cis-9, trans-11 CLA and VA by 300 to $400 \%$, respectively.

In previous studies (Dhiman et al., 2000; AbuGhazaleh et al., 2002; Whitlock et al., 2002; AbuGhazaleh et al., 2003a), fat supplements were fed for not more than 5 wk. However, because rumen microorganisms can adapt to diets and alter ruminal fermentation and metabolism makes us question whether dairy cows can maintain that high positive response in milk cis-9, trans-11 CLA content when a blend of fish oil and linoleic acid source is fed for a longer period of time, or will the increase in milk cis-9, trans-11 CLA and VA recede over time. Whitlock et al. (2002) observed a higher concentration of milk cis-9, trans-11 CLA and VA during wk 2 compared with wk 3 and 4 of treatments. Similar results were also reported by Dhiman et al. (2000) when cows fed soybean oil at $2 \%$ of diet DM. However, Loor et al. (2002) reported a gradual increase in milk yields of cis-9, trans-11 CLA from wk 0 through 8 when cows were grazed and fed mechanically extracted soybean meal. We are not aware of published studies that have evaluated the effects of feeding a CLA-stimulating TMR diets for an extended period of time on milk cis-9, trans11 CLA. Thus the objective of this study was to test the effect of feeding fish oil from fish meal and extruded soybeans (linoleic acid source) for an extended period of time on milk cis-9, trans-11 CLA and VA.

\section{MATERIALS AND METHODS}

All procedures for this study were conducted under approval of the South Dakota State University Institutional Animal Care and Use Committee. Twenty lactating cows (16 Holstein cows and 4 Brown Swiss), 89 ( \pm 32) DIM, were housed in a free-stall barn at South Dakota State University dairy farm and fed individually using Calan Broadbent feeder doors (American Calan, Inc., Northwood, NH). During the first $2 \mathrm{wk}$, all cows were fed the control diet and production, and milk composition data were used for covariance analysis. Cows were divided into 2 groups (10 cows/treatment) starting on wk 3 according to DIM, milk production, breed, and parity (8 primiparous). Group 1 remained on the control diet, while the second group was fed the treatment diet for the next $10 \mathrm{wk}$. Diets (Table 1) consisted of (DM basis) 50\% concentrate mix, 25\% corn
Table 1. Ingredient and nutrient content of experimental diets.

\begin{tabular}{|c|c|c|}
\hline \multirow[b]{2}{*}{ Item } & \multicolumn{2}{|c|}{$\operatorname{Diets}^{1}$} \\
\hline & Control & FMESB \\
\hline & $\longrightarrow$ & \\
\hline \multicolumn{3}{|l|}{ Ingredient composition } \\
\hline Alfalfa hay & 25.00 & 25.00 \\
\hline Corn silage & 25.00 & 25.00 \\
\hline Cracked corn & 26.86 & 28.76 \\
\hline Soybean meal, $44 \% \mathrm{CP}$ & 17.58 & 0.54 \\
\hline Extruded soybeans & 0.00 & 10.64 \\
\hline${\text { Fish } \text { meal }^{2}}^{2}$ & 0.00 & 5.50 \\
\hline Soybean hulls & 3.50 & 3.00 \\
\hline Limestone & 0.86 & 0.86 \\
\hline Dicalcium phosphate & 0.50 & 0.00 \\
\hline Magnesium oxide & 0.14 & 0.14 \\
\hline Salt-TM (high Zn) & 0.20 & 0.20 \\
\hline Sodium bicarbonate & 0.20 & 0.20 \\
\hline Vitamin E premix ${ }^{3}$ & 0.06 & 0.06 \\
\hline Vitamin $\mathrm{A}, \mathrm{D}, \& \mathrm{E}$ premix $^{4}$ & 0.10 & 0.10 \\
\hline \multicolumn{3}{|l|}{ Chemical composition } \\
\hline $\mathrm{DM}, \%$ & 59.80 & 60.10 \\
\hline $\mathrm{CP}$ & 18.40 & 17.44 \\
\hline $\mathrm{RUP}^{5}, \%$ of CP & 32.51 & 42.63 \\
\hline Ether extract & 2.67 & 4.93 \\
\hline Total fatty acids & 1.60 & 3.55 \\
\hline $\mathrm{ADF}$ & 18.53 & 17.94 \\
\hline $\mathrm{NDF}$ & 30.44 & 28.37 \\
\hline Lignin & 4.40 & 4.02 \\
\hline Ash & 7.34 & 7.29 \\
\hline $\mathrm{Ca}$ & 1.25 & 1.42 \\
\hline $\mathrm{P}$ & 0.51 & 0.54 \\
\hline $\mathrm{Mg}$ & 0.39 & 0.38 \\
\hline $\mathrm{K}$ & 0.40 & 1.17 \\
\hline $\mathrm{NE}_{\mathrm{L}}^{5}, \mathrm{Mcal} / \mathrm{kg}$ & 1.67 & 1.69 \\
\hline
\end{tabular}

${ }^{1}$ Control $=$ No supplemental fat; FMESB $=0.5 \%$ fish oil from fish meal $+2.0 \%$ soybean oil from extruded soybeans.

${ }^{2}$ Sea Lac; Omega Protein Inc., Hammond, LA.

${ }^{3}$ Contain 44,000 IU of vitamin E/kg.

${ }^{4}$ Contained 4,400,000 IU of vitamin A, 880,000 IU of vitamin D, and $400 \mathrm{IU}$ of vitamin $\mathrm{E} / \mathrm{kg}$.

${ }^{5}$ Estimated from the NRC (2001).

silage, and 25\% alfalfa hay. Experimental concentrate mixes were 1) control, which contained primarily corn and soybean meal in the concentrate mixture and 2) $0.5 \%$ fish oil from fish meal and $2 \%$ soybean oil from extruded soybean mean (FMESB), which replaced nearly all of the soybean meal. Menhaden fish meal (ruminant grade, Sea Lac; Omega Protein, Inc., Hammond, LA) was used. Extruded soybeans (Triple F Feeds, Des Moines, IA) were obtained from a local dealer. Diets were formulated to meet nutrient requirements according to NRC (2001). Cows were individually fed a TMR once daily $(0700 \mathrm{~h}$ ) for ad libtium consumption with continuous access to feed except during milking. Amounts fed and refused were recorded daily.

Cows were milked daily at 0600, 1400, and $2100 \mathrm{~h}$, and milk yield was recorded at each milking. Milk samples from the 3 daily milkings were collected at the end of each week throughout the 12-wk experiment. 


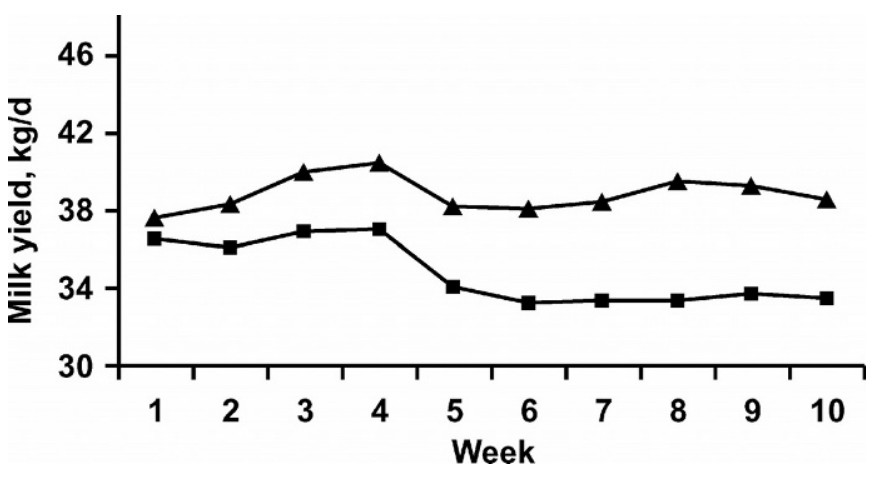

Figure 1. Changes in milk yield with time for cows fed the control $(\mathbb{\square})$ or the fish meal and extruded soybeans (A) diet. SEM averaged 0.1.27.

Twenty-four hour composites of each cow's milk, amounts proportional to milk yield at each milking, were divided into 2 portions for analysis. One portion was refrigerated at $4^{\circ} \mathrm{C}$ and sent to a laboratory (Valley Queen Cheese Factory, Milbank, SD) to be analyzed for fat, protein, lactose, and SNF (AOAC, 1997) by mid infrared spectrophotometry (Multispec; Foss Food Technology Corp., Eden Prairie, MN). Somatic cell counts were determined using a Fossomatic 90 (Foss Food Technology Corp., Eden Prairie, MN). The other portion of each sample was stored at $-20^{\circ} \mathrm{C}$ for fatty acid analysis by GLC as described by AbuGhazaleh et al. (2003a).

Samples of alfalfa hay, corn silage, and concentrate mixes were collected on wk $1,3,5,7,9$, and 12 , dried at $55^{\circ} \mathrm{C}$ for $48 \mathrm{~h}$, and then ground through a standard model no. 3 Wiley mill (Arthur H. Thomas Co., Philadelphia, PA) with a 2-mm screen. Ground feed samples were sent to feed commercial laboratory (Dairy Land Laboratories, Inc., Arcadia, WI) for analysis. Contents of $\mathrm{CP}$, ether extract, ash, $\mathrm{Ca}, \mathrm{P}, \mathrm{K}$, and $\mathrm{Mg}$ were determined by AOAC (1997) methods. A portion of each sample was reground through an ultracentrifuge mill

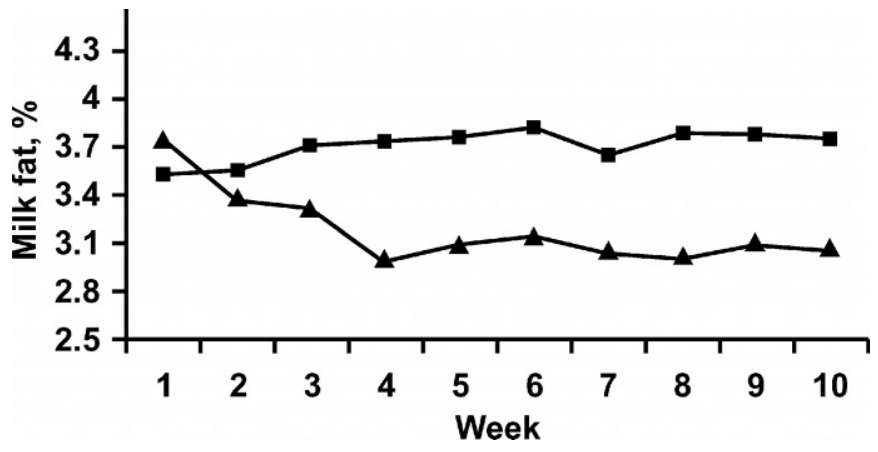

Figure 2. Changes in milk fat percentages with time for cows fed

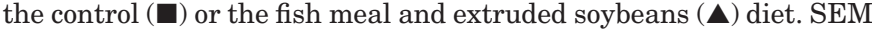
averaged 0.11 .
(Brinkman Instruments Co., Westbury, NY) with a 1$\mathrm{mm}$ screen and analyzed for NDF (Procedure B, Van Soest et al., 1991), ADF (Robertson and Van Soest, 1981), and acid detergent lignin (Lowry et al., 1994) using ANKOM fiber analyzer using the filter bag technique (ANKOM Technology Corp., Fairport, NY).

Samples of alfalfa hay, corn silage, and concentrate mix from wk 1, 3, 5, 7, 9, and 12 were composited into a TMR by week. Fat was extracted from these samples with a mixture of ether and acetone (1:1 vol/vol). Approximately $15 \mathrm{mg}$ of the extracted fat was transferred into $13-\times 100-\mathrm{mm}$ test tubes with Teflon-lined screw caps and analyzed for fatty acids as described by AbuGhazaleh et al. (2003b). The C17:0 FA, dissolved in butanol, was used as an internal standard.

Body weight and BCS for each cow was recorded at the beginning and end of the study. Cows were body scored by the same individual on a 5-point system (Wildman et al., 1982).

Analysis of variance was conducted using the MIXED procedure of SAS (1996) for a completely randomized design with repeated measures. Data from first $2 \mathrm{wk}$ were used for covariance analysis for all variables. The model contained the effects of covariance, treatment, week, treatment $\times$ week interaction, breed, and parity. Cow within treatment was used as an error term. Least squares means are reported throughout, and significance was declared at $(P<0.01)$ unless otherwise noted.

\section{RESULTS AND DISCUSSION}

The ingredient and chemical composition of diets are presented in Table 1 . The diets were formulated to contain approximately $18 \% \mathrm{CP}, 29 \% \mathrm{NDF}$, and $19 \% \mathrm{ADF}$ (Table 1). However, chemical analysis of dietary samples found the CP concentration was lower for the FMESB diet than anticipated. The lower than anticipated percentage of CP for the FMESB diet was attributed to slightly lower CP content of fish meal and extruded soybeans than values used to formulate the diet. Total fatty acids were measured because they better represent the true nutritional value of dietary fat than ether extract.

\section{Milk Yield, Milk Composition, and Dry Matter Intake}

Cows fed the FMESB diet produced $4.3 \mathrm{~kg} / \mathrm{d}$ more milk $(P<0.01)$ than those fed the control diet (Table 2 ), which was consistent with our previous observation when cows were fed similar diets (AbuGhazaleh et al., 2002). Others have also observed increase in milk yields for diets supplemented with extruded soybeans as reviewed by Satter et al. (1994). The higher milk yield by the FMESB diet was maintained throughout the 
Table 2. Milk yield, milk composition, DMI, BW, and BCS for cows fed the control diet, and the fish meal with extruded soybeans diet (FMESB).

\begin{tabular}{|c|c|c|c|c|c|}
\hline \multirow[b]{2}{*}{ Item } & \multicolumn{2}{|c|}{ Diet $^{1}$} & \multirow[b]{2}{*}{ SEM } & \multicolumn{2}{|c|}{$P$ Value } \\
\hline & Control & FMESB & & Trt & $\operatorname{Trt} \times w_{k}$ \\
\hline Milk, kg/d & 34.5 & 38.9 & 1.13 & 0.01 & $>0.01$ \\
\hline $3.5 \%$ FCM, kg/d & 36.0 & 36.4 & 1.05 & 0.76 & 0.37 \\
\hline $\mathrm{ECM}^{3}, \mathrm{~kg} / \mathrm{d}$ & 36.4 & 37.3 & 1.06 & 0.60 & 0.42 \\
\hline \multicolumn{6}{|l|}{ Fat } \\
\hline$\%$ & 3.74 & 3.17 & 0.09 & 0.01 & $>0.01$ \\
\hline $\mathrm{kg} / \mathrm{d}$ & 1.29 & 1.21 & 0.04 & 0.20 & 0.01 \\
\hline \multicolumn{6}{|l|}{ Protein } \\
\hline$\%$ & 3.39 & 3.18 & 0.04 & 0.01 & 0.05 \\
\hline kg/d & 1.16 & 1.23 & 0.04 & 0.17 & 0.03 \\
\hline \multicolumn{6}{|l|}{ Lactose } \\
\hline$\%$ & 4.78 & 4.78 & 0.03 & 0.98 & 0.45 \\
\hline $\mathrm{kg} / \mathrm{d}$ & 1.65 & 1.86 & 0.06 & 0.03 & 0.01 \\
\hline \multicolumn{6}{|l|}{ Solids } \\
\hline$\%$ & 5.85 & 5.85 & 0.04 & 0.96 & 0.21 \\
\hline $\mathrm{kg} / \mathrm{d}$ & 2.02 & 2.27 & 0.07 & 0.03 & 0.01 \\
\hline $\mathrm{SCC}, \times 10^{3} / \mathrm{mL}$ & 95.3 & 76.4 & 31 & 0.70 & 0.29 \\
\hline DMI. Kg/d & 29.3 & 27.7 & 0.72 & 0.10 & 0.14 \\
\hline $\mathrm{BW}, \mathrm{kg}$ & 618 & 598 & 11.80 & 0.45 & \\
\hline $\mathrm{BCS}^{4}$ & 2.91 & 2.85 & 0.10 & 0.52 & \\
\hline
\end{tabular}

${ }^{1}$ Control $=$ No supplemental fat FMESB $=0.5 \%$ fish oil from fish meal $+2.0 \%$ soybean oil from extruded soybeans.

${ }^{2}$ Treatment $\times$ week interaction effect.

${ }^{3} \mathrm{ECM}=$ Energy-corrected milk (Orth, 1992).

${ }^{4}$ Scored on a five-point scale where $1=$ emaciated to $5=$ overly fat (Wildman et al., 1982).

study (Figure 1). In contrast to milk yield, energy-corrected milk and FCM were similar $(P=0.60)$ for both diets, because of the lower milk fat test $(P<0.01)$ with the FMESB diet (Table 2).

Milk fat percentages were decreased $(P<0.01)$ by the FMESB diet. The same effect was observed in previous studies (AbuGhazaleh et al., 2002; Whitlock et al., 2002) when a blend of fish oil and extruded soybeans was fed. However, due to the higher milk yield with the FMESB diet, milk fat yields were similar $(P=0.20)$ for both treatments. Week $\times$ treatment interaction effect was significant $(P<0.01)$ for milk fat. The reduction in milk fat percentages with the FMESB diet had occurred by the end of the first week of fat supplementation, continued to decrease during wk 2,3 , and 4 , and then remained relatively constant until the end of the experiment (Figure 2).

Milk true protein percentages decreased $(P<0.01)$ by the FMESB diet when compared to the control diet (Table 2). However, daily yields of milk protein were similar for both diets because of the higher milk yield with the FMESB diet. Milk protein percentages often decrease when supplemental fat is fed to lactating dairy cows (DePeters and Cant, 1992; Wu and Huber, 1994).

The DMI was similar $(P=0.10)$ for both diets (Table 2 ); however, intakes were numerically lower with the FMESB diet compared with the control diet. These results suggest that feeding oil through heat-treated soy- beans in the FMESB treatment had little negative influence on feed intake. Similar effects were reported previously (AbuGhazaleh et al., 2002; Whitlock et al., 2002). Treatments showed no effect on lactose percentages, solids percentages, SCC, BW, or BCS (Table 2). However, because of higher milk yield with the FMESB diet, both lactose and solids yields were higher $(P<$ 0.01) with the FMESB diet.

\section{Fatty Acid Composition of Feed and Milk}

Daily intakes of individual fatty acids and fatty acid compositions of fat supplements are presented in Table 3. As expected, linoleic acid (C18:2 cis-9, cis-12; 51\%) was the major fatty acid present in extruded soybeans. Fish meal was characterized by its long-chain fatty acids; eicosapentaenoic acid (EPA; 20:5) and docosahexaenoic acid, (DHA; 22:6), and low concentrations of linoleic acid. The addition of extruded soybeans increased total intake of oleic (C18:1 cis-9), linoleic, and linolenic (18:3 cis-9, cis-12, cis-15) acids compared with cows fed the control diet (Table 3). For the FMESB diet, the intake of oleic, linoleic, and linolenic acids represented 18.0, 43.0, and 7.0\% of total fatty acids, respectively. Oleic, linoleic, and linolenic acids are all precursors for synthesis of $c i s-9$, trans-11 CLA, VA, and other trans C18:1 and CLA isomers during the ruminal 
Table 3. Fatty acid intake of dietary treatments, and fatty acid composition of extruded soybeans, and fish meal.

\begin{tabular}{|c|c|c|c|c|}
\hline \multirow[b]{2}{*}{ Fatty acids ${ }^{2}$} & \multicolumn{2}{|c|}{$\operatorname{Diets}^{1}$} & \multirow{2}{*}{$\begin{array}{l}\text { Extruded } \\
\text { soybeans }\end{array}$} & \multirow{2}{*}{$\begin{array}{l}\text { Fish } \\
\text { meal }\end{array}$} \\
\hline & Control & FMESB & & \\
\hline & \multicolumn{2}{|c|}{$\longrightarrow(\mathrm{g} / \mathrm{d})$} & \multicolumn{2}{|c|}{$-(\mathrm{g} / 100 \mathrm{~g}$ of fatty acids $)-$} \\
\hline C14:0 & 1.13 & 7.18 & $\mathrm{nd}^{3}$ & 7.67 \\
\hline C16:0 & 62.90 & 125.88 & 11.45 & 20.49 \\
\hline C16:1 & 1.13 & 9.05 & 0.08 & 9.98 \\
\hline C17:0 & 0.80 & 1.87 & 0.10 & 0.94 \\
\hline C18:0 & 11.49 & 32.35 & 4.10 & 3.95 \\
\hline C18:1c9 & 80.63 & 174.26 & 20.95 & 5.59 \\
\hline C18:1c11 & 4.92 & 14.95 & 1.84 & 2.99 \\
\hline C18:2c9c12 & 198.80 & 425.00 & 51.32 & 1.25 \\
\hline C18:3n6 & 0.47 & 0.98 & nd & 0.06 \\
\hline C18:3n3 & 38.44 & 68.35 & 7.98 & 1.28 \\
\hline C20:0 & 1.97 & 3.34 & 0.29 & 0.19 \\
\hline C21:0 & nd & 1.48 & nd & 2.06 \\
\hline C23:0 & nd & 0.79 & nd & 1.10 \\
\hline C20:5 (EPA) & 0.14 & 6.39 & nd & 9.13 \\
\hline $\mathrm{C} 22: 5$ & nd & 1.08 & nd & 1.81 \\
\hline C22:6 (DHA) & nd & 5.31 & nd & 9.12 \\
\hline Others $^{4}$ & 66.0 & 104.7 & 1.89 & 22.39 \\
\hline
\end{tabular}

${ }^{1}$ Control $=$ No supplemental fat FMESB $=0.5 \%$ fish oil from fish meal $+2.0 \%$ soybean oil from extruded soybeans.

${ }^{2}$ Expressed as number of carbons:double bonds.

${ }^{3} \mathrm{nd}=$ Not detectable or detected at $<0.01$.

${ }^{4}$ Unidentified fatty acids.

biohydrogenation process (Harfoot and Hazlewood, 1988; Mosley et al., 2002).

Milk from cows fed the FMESB diet had lower $(P<$ $0.01)$ concentration of total short-chain fatty acids (C4:0 to C12:0) and medium-chain fatty acids (C14:0 to C16:0) and a greater $(P<0.01)$ concentration of long-chain fatty acids compared with the control diet (Table 4). Feeding polyunsaturated fat is typically associated with a decrease in the de novo synthesis of short and medium-chain fatty acids (Casper et al., 1988; AbuGhazaleh et al., 2002), with the greatest decrease when a high linoleic acid source was fed (Casper et al., 1988; Kelly et al., 1998; AbuGhazaleh et al., 2003a). The decrease in medium-chain fatty acids may represent an improvement in the profile of milk fat fatty acids as these fatty acids have been reported to constitute the hypercholesterolemic portion of milk fat (Ney, 1991).

Concentrations of stearic (C18:0), oleic, linoleic, and linolenic acids increased in milk fat $(P<0.01)$ when the FMESB diet was fed. The average increases in the concentrations of stearic, oleic, linoleic, and linolenic acids were $17,22,45$, and $17 \%$, respectively, with the FMESB diet compared with the control diet. Increases in the concentration of these fatty acids with the FMESB diet can be attributed to their higher intake (Table 3), and to the reduction in milk short-chain fatty acids (Table 4). Feeding oil through seeds increases the availability of unsaturated fatty acids in the small intestine. Increases in the concentration of milk stearic acid with the FMESB diet can also be attributed to the complete ruminal biohydrogenation of some mono- and polyunsaturated fatty acids supplied by the FMESB diet. The concentrations of trans-9 C18:1, trans -10 C18:1, and VA increased $(P<0.01)$ with the FMESB diet compared with the control diet. Kalscheur et al. (1997) observed an increase in the flow of trans C18:1 fatty acids, the products of incomplete ruminal biohydrogenation, into the duodenum when unsaturated fat was added to the diet of lactating cows. The increase in C18:1 trans fatty acids in milk fat in the current study is due to incomplete biohydrogenation in the rumens of cows fed the FMESB diet. Differences in yields of individual fatty acids followed the same pattern with regards to their concentration in milk fat (data not shown).

The main objective of this study was to examine the effect over time of the FMESB diet on milk cis-9, trans11 CLA. We are not aware of published studies that have evaluated the effects of feeding a CLA-stimulating TMR diets for an extended period of time on milk cis9, trans-11 CLA. In a 4-wk study, Whitlock et al. (2002) observed higher milk cis-9, trans-11 CLA concentration during wk 2 compared with wk 3 and 4 . Loor et al. (2002) reported a gradual increase in milk yields of $\mathrm{cis}$ 9, trans-11 CLA from wk 0 through 8 when cows were grazed and fed mechanically extracted soybean meal. In the current study, the concentrations and yields of milk cis-9, trans-11 CLA during the 10-wk experiment 
Table 4. Fatty acid composition of milk fat.

\begin{tabular}{|c|c|c|c|c|c|}
\hline \multirow[b]{2}{*}{ Fatty acids ${ }^{2}$} & \multicolumn{2}{|c|}{$\operatorname{Diets}^{1}$} & \multirow[b]{2}{*}{ SEM } & \multicolumn{2}{|c|}{$P$ Value } \\
\hline & Control & FMESB & & Trt & $\operatorname{Trt} \times w_{k}^{3}$ \\
\hline & $\longrightarrow(\mathrm{g} / 1$ & y acids) - & & & \\
\hline $\mathrm{C} 4: 0$ & 3.69 & 3.52 & 0.09 & 0.20 & 0.07 \\
\hline C6:0 & 2.42 & 2.11 & 0.06 & 0.01 & 0.42 \\
\hline $\mathrm{C} 8: 0$ & 1.50 & 1.26 & 0.04 & 0.01 & 0.57 \\
\hline C10:0 & 3.52 & 2.78 & 0.08 & 0.01 & 0.86 \\
\hline C12:0 & 4.12 & 3.23 & 0.09 & 0.01 & 0.66 \\
\hline C14:0 & 11.60 & 10.43 & 0.18 & 0.01 & 0.38 \\
\hline C14:1 & 1.72 & 1.48 & 0.05 & 0.01 & 0.13 \\
\hline C15:0 & 1.22 & 1.01 & 0.04 & 0.01 & 0.25 \\
\hline C16:0 & 31.69 & 25.46 & 0.36 & 0.01 & 0.03 \\
\hline C16:1 & 2.13 & 1.92 & 0.06 & 0.03 & 0.80 \\
\hline C17:0 & 0.57 & 0.47 & 0.01 & 0.01 & 0.01 \\
\hline C18:0 & 6.70 & 7.84 & 0.23 & 0.01 & 0.11 \\
\hline C18:1t6-8 & 0.20 & 0.19 & 0.01 & 0.71 & 0.19 \\
\hline C18:1t9 & 0.20 & 0.47 & 0.02 & 0.01 & 0.54 \\
\hline C18:1t10 & 0.36 & 0.75 & 0.03 & 0.01 & $>0.01$ \\
\hline C18:1t11 (VA) & 0.58 & 2.10 & 0.09 & 0.01 & $>0.01$ \\
\hline $\mathrm{C} 18: 1 \mathrm{c} 9$ & 15.40 & 18.81 & 0.33 & 0.01 & 0.23 \\
\hline C18:1c11 & 0.78 & 0.95 & 0.03 & 0.01 & 0.15 \\
\hline C18:2t9t12 & 0.24 & 0.53 & 0.02 & 0.01 & 0.27 \\
\hline C18:2c9c12 & 1.99 & 2.88 & 0.06 & 0.01 & 0.44 \\
\hline C18:2c9t11 (CLA) & 0.33 & 1.16 & 0.06 & 0.01 & $>0.01$ \\
\hline C18:2t10c12 & $>0.01$ & 0.04 & $>0.01$ & 0.01 & 0.02 \\
\hline C18:2t9t11 & 0.05 & 0.11 & $>0.01$ & 0.01 & 0.01 \\
\hline C18:3n6 & 0.11 & 0.21 & $>0.01$ & 0.01 & 0.01 \\
\hline C18:3n3 & 0.46 & 0.54 & 0.01 & 0.01 & 0.13 \\
\hline C20:0 & 0.09 & 0.14 & $>0.01$ & 0.01 & 0.16 \\
\hline C21:0 & 0.01 & 0.04 & $>0.01$ & 0.01 & 0.21 \\
\hline $\mathrm{C} 20: 2$ & 0.11 & 0.09 & $>0.01$ & 0.01 & 0.35 \\
\hline $\mathrm{C} 22: 0$ & 0.04 & 0.06 & $>0.01$ & 0.01 & 0.19 \\
\hline C22:1 & 0.15 & 0.14 & $>0.01$ & 0.07 & 0.25 \\
\hline C23:0 & 0.02 & 0.04 & $>0.01$ & 0.01 & 0.32 \\
\hline C20:5 (EPA) & 0.01 & 0.07 & $>0.01$ & 0.01 & 0.03 \\
\hline $\mathrm{C} 22: 5$ & 0.05 & 0.07 & $>0.01$ & 0.01 & 0.10 \\
\hline C22:6 (DHA) & $\mathrm{nd}^{4}$ & 0.07 & $>0.01$ & 0.01 & 0.01 \\
\hline Others $^{5}$ & 7.75 & 9.23 & 0.20 & 0.01 & 0.42 \\
\hline Short $^{6}$ & 15.27 & 12.90 & 0.28 & 0.01 & 0.36 \\
\hline Medium $^{7}$ & 46.39 & 38.15 & 0.41 & 0.01 & 0.12 \\
\hline Long $^{8}$ & 30.60 & 39.72 & 0.52 & 0.01 & 0.03 \\
\hline
\end{tabular}

\footnotetext{
${ }^{1}$ Control $=$ No supplemental fat FMESB $=0.5 \%$ fish oil from fish meal $+2.0 \%$ soybean oil from extruded soybeans.

${ }^{2}$ Expressed as number of carbons:double bonds.

${ }^{3}$ Treatment $\times$ week interaction effect.

${ }^{4} \mathrm{nd}=$ Not detectable or detected at $<0.01$.

${ }^{5}$ Unidentified fatty acids.

${ }^{6}$ Short $=$ Short-chain fatty acids (C4:0 to C12:0).

${ }^{7}$ Medium = Medium-chain fatty acids (C14:0 to C16:0).

${ }^{8}$ Long $=$ Long-chain fatty acids (> C16:0).
}

averaged $250 \%$ higher for cows fed the FMESB diet compared with cows fed the control diet (Table 4). The increase in cis-9, trans-11 CLA observed with the FMESB diet was similar to our previous results (AbuGhazaleh et al., 2002; Whitlock et al., 2002). The week $\times$ treatment interaction was significant $(P<0.01)$ for cis-9, trans-11 CLA (Figure 3), suggesting that this isomer in milk fat varied among treatments during the sampling weeks. Milk cis-9, trans-11 CLA response to the FMESB diet was fast. The increase in concentration of milk cis-9, trans-11 CLA with the FMESB diet occurred by the end of the first week of fat supplementation and remained consistently higher than that of the control diet throughout the experiment period (Figure 3). Concentration of milk cis-9, trans-11 CLA did not change throughout the experiment in cows fed the control diet (Figure 3). However, in cows fed the FMESB diet, concentration of milk cis-9, trans-11 CLA increased $160 \%$ by the end of the first week of fat supplementation, and reached its highest by wk 3 (350\% in- 


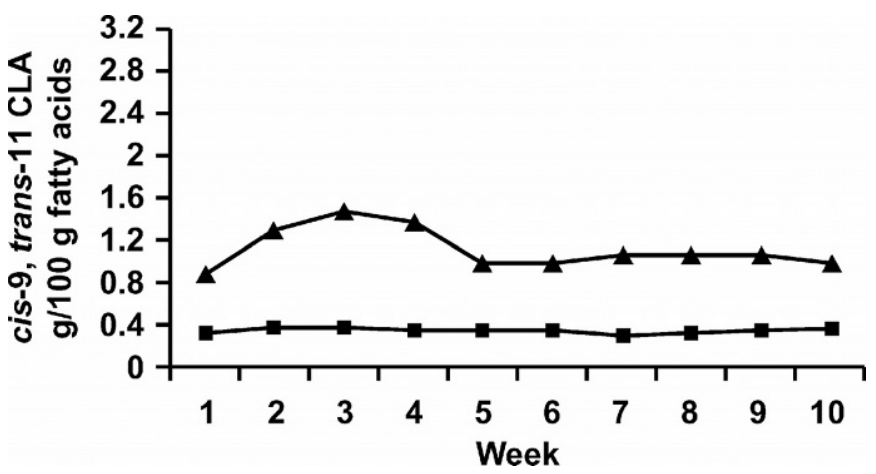

Figure 3. Changes in milk cis-9, trans-11 conjugated linoleic acid concentration with time for cows fed the control (ם) or the fish meal and extruded soybeans ( $\mathbf{\Delta}$ ) diet. SEM averaged 0.08.

crease). The highest concentration was $1.48 \mathrm{~g} / 100 \mathrm{~g}$ of fatty acids for the FMESB diet by wk 3 of fat supplementation. The concentration of milk cis-9, trans-11 CLA then declined from wk 3 to 5 of fat supplementation, and then remained relatively constant at approximately $230 \%$ higher than the control throughout the reminder of the experiment. These changes in milk concentration of cis-9, trans-11 CLA over time suggest a form of adaptation in the rumen occurred when cows fed a CLA-stimulating diet. Changes in rumen microbial populations and/or microbial enzyme activities over time with added fat are possible explanations for this pattern of changes in milk cis-9, trans-11 CLA concentration patterns.

Another objective of this experiment was to look at the effect of treatment on milk VA concentration. The human body can convert VA into cis-9, trans-11 CLA (Salminen et al., 1998), making an increase in milk VA concentration just as beneficial as an increase in cis9, trans-11 CLA concentration. The concentration and yield of milk VA was increased by 262 , and $252 \%$ with the FMESB diet, respectively, compared with the control diet (Table 4). Similar increases in milk VA concentrations and yields were observed previously (AbuGhazaleh et al., 2002, 2003a; Whitlock et al., 2002) when cows were fed a blend of fish oil and extruded soybeans. Similarly to milk cis-9, trans-11 CLA, a week $\times$ treatment interaction was significant $(P<0.01)$ for VA (Figure 4). The concentration of VA in milk fat from cows fed the FMESB diet doubled by the end of the first week of fat supplementation, continued to increase during wk 2 , reached a maximum $(2.89 \mathrm{~g} / 100 \mathrm{~g}$ of fatty acids) by wk 3 of fat supplementation. The concentration of milk VA then declined after wk 3 of fat supplementation, and by wk 5 of fat supplementation, the increase in milk VA concentration was dropped to approximately $200 \%$. The concentration of milk VA re-

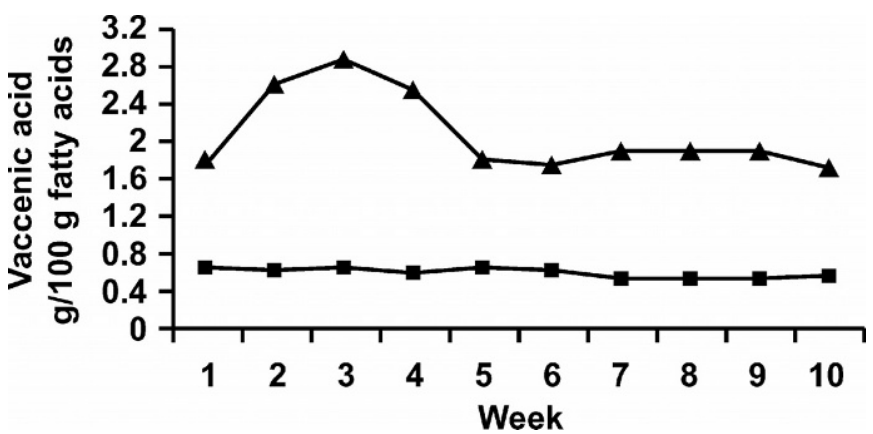

Figure 4. Changes in milk vaccenic acid concentration with time for cows fed the control (ם) or the fish meal and extruded soybeans (ム) diet. SEM averaged 0.12.

mained relatively constant after wk 5 of fat supplementation and throughout the remainder of the experiment at approximately $225 \%$ higher than concentrations when fed the control diet (Figure 4). The effect of treatment diets in yields of cis-9, trans-11 CLA and VA over time followed the same pattern as for their concentration in milk fat (data not shown).

Another CLA isomer of interest is trans-10, cis-12, which originates in the rumen from the biohydrogenation of linoleic acid via cis-9, trans-10 isomerase enzyme (Griinari and Bauman, 1999). Recent studies (Baumgard et al., 2002; Peterson et al., 2002) indicated that trans-10, cis-12 CLA is primarily responsible for decreased milk fat content. In this study, milk fat content of trans-10, cis-12 CLA was higher $(P<0.01)$ for the FMESB diet compared with the control diet (Table 4). The increase in milk fat content of trans-10, cis-12 CLA with the FMESB diet was apparent by the end of first week of fat supplement (Figure 5). While concentrations of trans-10, cis-12 CLA were extremely small, the concentrations in milk fat gradually increased from wk 1 through wk 4 of fat supplement when concentration

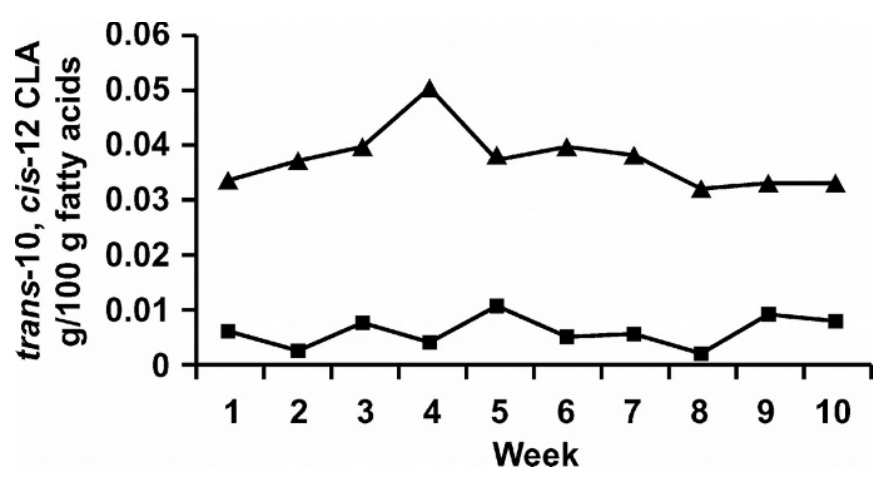

Figure 5. Changes in milk trans-10, cis-12 conjugated linoleic acid concentration with time for cows fed the control (ם) or the fish meal and extruded soybeans $(\mathbf{\Lambda})$ diet. SEM averaged $<0.01$. 


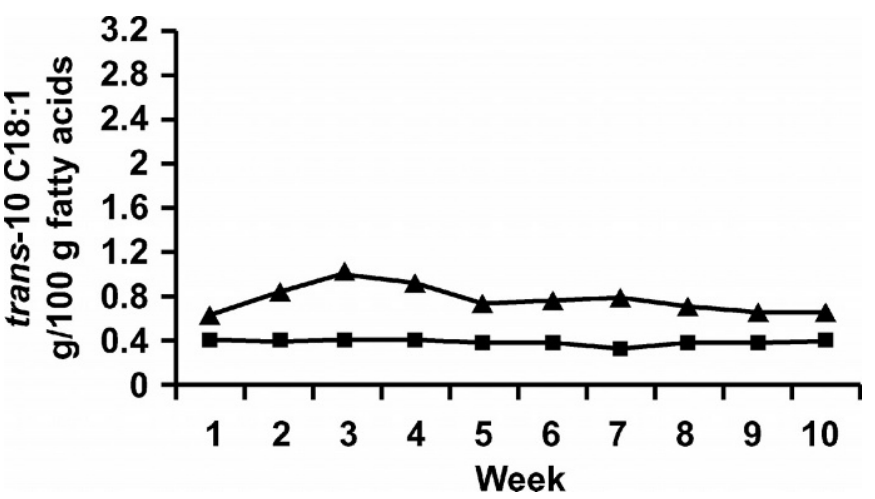

Figure 6. Changes in milk trans-10 C18:1 concentration with time for cows fed the control (ם) or the fish meal and extruded soybeans (A) diet. SEM averaged 0.06 .

was approximately 10 -fold greater than that of the control diet, then declined to lower concentration throughout the remainder of the experiment (Figure 5). The increased concentrations of trans-10, cis-12 CLA in milk fat closely paralleled the pattern of decreased in milk fat percentages (Figures 2 and 5). This reverse relationship between milk fat percentage and milk fat content of trans-10, cis-12 CLA further supports the role of this fatty acid in milk fat depression (Baumgard et al., 2002). It appeared that, under this experimental diet, rumen conditions that favor trans-10, cis-12 CLA production do not continue to increase gradually over time as seen by Loor et al. (2002).

Trans-10 C18:1 fatty acid is another isomer of particular importance because at high concentrations (16\% of total milk fatty acids), it was associated with milk fat depression (Piperova et al., 2000). The concentration of trans-10 C18:1 in milk fat was also higher in cows fed the FMESB diet. The increased concentrations of trans-10 C18:1 in milk fat also closely paralleled the pattern of decreased in milk fat percentages, also demonstrating some role of this fatty acid in milk fat depression (Figures 2 and 6).

Fish oil in fish meal is a good source for the omega3 fatty acids (EPA and DHA; Table 2). The concentrations of EPA and DHA in milk fat were increased $(P<$ 0.01) when cows were fed the FMESB diet, similar to the response observed in previous experiments when fish meal and fish oil were fed (Donovan et al., 2000; AbuGhazaleh et al., 2002; Whitlock et al., 2002). Cows fed the FMESB diet consumed an average 6.39 and 5.31 $\mathrm{g} / \mathrm{d}$ of EPA and DHA and secreted an average $0.9 \mathrm{~g} / \mathrm{d}$ of EPA and DHA in milk. This low transfer efficiency of EPA and DHA (14 and 17\%, respectively) from feed to milk was similar to reports by others (Franklin et al., 1999; Lacasse et al. 2002) when algae and fish oil were fed to lactating dairy cows. The low transfer effi- ciency of EPA and DHA from feed to milk fat may be because these 2 fatty acids are preferentially deposited in body tissue rather than in milk fat (Ashes et al., 1992) and/or because of their extensive rumen biohydrogenation of EPA and DHA (Wachira et al. 2000). There were no consistent patterns of change in the concentration of EPA and DHA in milk fat over time.

\section{CONCLUSIONS AND IMPLICATIONS}

Results showed that feeding lactating dairy cows a blend of fish meal and extruded soybeans increased milk production and the concentrations and yields of milk cis-9, trans-11 CLA and VA. The increase in concentration and yield of milk cis-9, trans-11 CLA and VA occurred within $1 \mathrm{wk}$ of adding the fat supplements to the diet, slightly continued to increase, reaching maximum by wk 3 , then gradually decreased to wk 5 , and remained relatively constant throughout the remainder of the study at substantially higher concentrations than if fed the control diet. In conclusion, yields of cis-9, trans-11 CLA and VA in milk fat can be increased by feeding a blend of fish meal and extruded soybeans. That increase is relatively constant after $5 \mathrm{wk}$ on the diet.

\section{ACKNOWLEDGMENTS}

We thank the employees of the South Dakota State University Dairy Research Facility for care of the cows and assistance in obtaining research data and Valley Queen Cheese Factory, Milbank, SD, for milk analysis.

\section{REFERENCES}

AbuGhazaleh, A. A., D. J. Schingoethe, A. R. Hippen, and K. F. Kalscheur. 2003a. Milk conjugated linoleic acid response to fish oil supplementation of diets differing in fatty acid profiles. J. Dairy Sci. 86:944-953.

AbuGhazaleh, A. A., D. J. Schingoethe, A. R. Hippen, and K. F. Kalscheur. 2003b. Conjugated linoleic acid and vaccenic acid in rumen, plasma, and milk of cows fed fish oil and fats differing in saturation of 18 carbon fatty acids. J. Dairy Sci. 86:3648-3660.

AbuGhazaleh, A. A., D. J. Schingoethe, A. R. Hippen, and L. A. Whitlock. 2002. Feeding fish meal and extruded soybeans enhances the conjugated linoleic acid (CLA) content of milk. J. Dairy Sci. 85:624-631.

Ashes, J. R., B. D. Siebert, S. K. Gulati, A. Z. Cuthbertson, and T. W. Scott. 1992. Incorporation of n-3 fatty acids of fish oil into tissue and serum lipids of ruminants. Lipids 27:629-631.

Association of Official Analytical Chemists. 1997. Official Methods of Analysis. 16th ed. AOAC Int., Gaithersburg, MD.

Baumgard, L. H., E. Matitashvili, B. A. Corl, D. A. Dwyer, and D. E. Bauman. 2002. Trans-10, cis-12 conjugated linoleic acid decrease lipogenic rates and expression of genes involved in milk lipid synthesis in dairy cows. J. Dairy Sci. 85:2155-2163.

Casper, D. P., D. J. Schingoethe, R. P. Middaugh, and R. J. Baer. 1988. Lactational responses of dairy cows to diets containing regular and high oleic sunflower seeds. J. Dairy Sci. 71:12671274.

Chouinard, P. Y., L. Corneau, W. R. Butler, Y. Chilliard, J. K. Drackley, and D. E. Bauman. 2001. Effect of dietary lipid source 
on conjugated linoleic acid concentrations in milk fat. J. Dairy Sci. 84:680-690.

DePeters, E. J., and J. P. Cant. 1992. Nutritional factors influencing the nitrogen composition of bovine milk: A review. J. Dairy Sci. 75:2043-2070.

Dhiman, T. R., L. D. Satter, M. W. Pariza, M. P. Galli, K. Albright, and M. X. Tolosa. 2000. Conjugated linoleic acid (CLA) content of milk from cows offered diets rich in linoleic and linolenic acid. J. Dairy Sci. 83:1016-1027.

Donovan, C. D., D. J. Schingoethe, R. J. Baer, J. Ryali, A. R. Hippen, and S. T. Franklin. 2000. Influence of dietary fish oil on conjugated linoleic acid and other fatty acids in milk fat from lactating dairy cows. J. Dairy Sci. 83:2620-2628.

Franklin, S. T., K. R. Martin, R. S. Baer, and D. J. Schingoethe. 1999. Dietary marine algae (Schizochytrium sp.) increases concentrations of conjugated linoleic acid, docosahexanoic acid, and transvaccenic acid of milk in dairy cow. J. Nutr. 129:2048-2052.

Griinari, J. M., and D. E. Bauman. 1999. Biosynthesis of conjugated linoleic acid and its incorporation into meat and milk in ruminants. Pages 180-200 in Recent Advances in Conjugated Linoleic Acid Research. M. P. Yurawecs, M. M. Mossoba, J. K. G. Kramer, G. Nelson and M. W. Pariza, ed. AOCS Press, Champaign, IL.

Harfoot, C. G., and G. P. Hazlewood. 1988. Lipid metabolism in the rumen. Pages 285-322 in The Rumen Microbial Ecosystem. P. N. Hobson, ed. Elsevier Applied Sci. Publ., London, UK.

Ip, C., S. Banni, E. Angioni, G. Carta, J. McGruley, H. J. Thompson, D. Barbano, and D. Bauman. 1999. Conjugated linoleic acid enriched butter fat alters morphogenesis and reduces cancer risk in rats. J. Nutr. 129:2135-2142.

Kalscheur, K. F., B. B. Teter, L. S. Piperova, and R. A. Erdman. 1997. Effect of fat source on duodenal flow of trans-C18:1 fatty acids and milk fat production in dairy cows. J. Dairy Sci. 80:2115-2126.

Kelly, M. L., J. R. Berry, D. A. Dwyer, J. M. Griinari, P. Y. Chouinard, M. E. Van Amburgh, and D. E. Bauman. 1998. Dietary fatty acid sources effect conjugated linoleic acid (CLA) concentrations in milk from lactating dairy cows. J. Nutr. 128:881-885.

Lacasse, P., J. J. Kennelly, L. Delbecchi, and C. E. Ahnadi. 2002. Addition of protected and unprotected fish oil to diets for dairy cows. 1. Effects on yield, composition and taste of milk. J. Dairy Res. 69:511-520.

Loor, J. J., J. H. Herbein, and C. E. Polan. 2002. Trans 18:1 and 18:2 isomers in blood plasma and milk fat of grazing cows fed a grain supplement containing solvent-extracted or mechanically extracted soybean meal. J. Dairy Sci. 85:1197-1207.

Lowry, J. B., L. L. Conlan, A. C. Schlink, and C. S. McSweeney. 1994. Acid detergent dispersible lignin in tropical grasses. J. Sci. Food Agric. 65:41-50.

Mosley, E. E., G. L. Powell, M. B. Riley, and T. C. Jenkins. 2002. Microbial biohydrogenation of oleic acid to trans isomers in vitro. J. Lipid Res. 43:290-296.

National Research Council. 2001. Nutrient Requirements of Dairy Cattle. 7th rev. ed. Natl. Acad. Sc., Washington, DC.
Ney, D. M. 1991. Potential for enhancing the nutritional properties of milk fat. J. Dairy Sci. 74:4002-4012.

Orth, R. 1992. Sample day and lactation report, DHIA 200. Fact Sheet A-2, Mid-states DRPC, Ames, IA.

Peterson, D. G., L. H. Baumgard, and D. E. Bauman. 2002. Dosedependent reduction in milk fat secretion with abomasal infusion of trans-10, cis-12 conjugated linoleic acid (CLA) and comparison to diet-induced milk fat depression. J. Dairy Sci. 85(Suppl. 1):703. (Abstr.)

Piperova, L. S., B. B. Teter, I. Bruckental, J. Sampugna, S. E. Mills, M. P. Yurawecz, J. Fritsche, Y. Ku, and R. A. Erdman. 2000. Mammary lipogenic enzyme activity, trans fatty acids and conjugated linoleic acids are altered in lactating dairy cows fed a milk fat-depressing diet. J. Nutr. 130:2568-2574.

Piperova, L. S., J. Sampugna, B. B. Teter, K. F. Kalscheur, M. P. Yurawecz, Y. Ku, K. M. Morehouse, and R. A. Erdman. 2002. Duodenal and milk trans octadecenoic acid and conjugated linoleic acid (CLA) isomers indicate that postabsorpative synthesis is the predominant source of cis-9-containing CLA in lactating dairy cows. J. Nutr. 132:1235-1241.

Robertson, J. B., and P. J. Van Soest. 1981. The detergent system of analysis and its application to human foods. Pages 123-129 in The Analysis of Dietary Fiber. W. P. T. James and O. Theander, eds. Marcel Dekker, New York, NY.

Salminen, I., M. Mutanen, M. Jauhiainen, and A. Aro.1998. Dietary trans fatty acids increase conjugated linoleic acid levels in human serum. J. Nutr. Biochem. 9:93-98.

SAS/STAT.1996. Software: Changes and Enhancements Through Release 6.11. SAS Inst., Inc., Cary, NC.

Satter, L. D., T. R. Dhiman, and J. T. Hsu. 1994. Use of heat processed soybeans in dairy rations. Pages 19-28 in Proc. Cornell Nutr. Conf. Feed Manuf., Cornell Univ., Ithaca, NY.

Van Soest, P. J., J. B. Robertson, and B. A. Lewis. 1991. Methods for dietary fiber, neutral detergent fiber, and non-starch polysaccharides in relation to animal nutrition. J. Dairy Sci. 74:35833597.

Wachira, A. M., L. A. Sinclair, R. G. Wilkinson, K. Hallett, M. Enser, and J. D. Wood. 2000. Rumen biohydrogenation of n-3 polyunsaturated fatty acids and their effects on microbial efficiency and nutrient digestibility in sheep. J. Agric. Sci. 135:419-428.

Whitlock, L., D. J. Schingoethe, A. R. Hippen, K. F. Kalscheur, R. J. Baer, N. Ramaswamy, and K. M. Kasperson. 2002. Fish oil and extruded soybeans fed in combination increase CLA in milk of dairy cows more than when fed separately. J. Dairy Sci. 85:234-243.

Wildman, E. E., G. M. Jones, P. E. Wagner, R. L. Bowman, H. F. Troutt, and T. N. Lesch. 1982. Dairy cow body condition scoring and its relationship to selected production characteristics. J. Dairy Sci. 65:495-501.

Wu, Z., and J. T. Huber. 1994. Relationship between dietary fat supplementation and milk protein concentration in lactating cows: A review. Livest. Prod. Sci. 39:141-155. 